\title{
Age estimation of the Atlantic bonito in the eastern Mediterranean Sea using dorsal spines and validation of the method
}

\author{
NIKOLAOS ZABOUKAS and PERSEFONI MEGALOFONOU \\ Department of Zoology-Marine Biology, Faculty of Biology, National and Kapodistrian University of Athens, \\ Panepistimiopolis, Athens 157 84, Greece. E-mail: zaboukas@biol.uoa.gr
}

\begin{abstract}
SUMMARY: Growth parameters were studied in 397 specimens of the Atlantic bonito caught in the eastern Mediterranean Sea (Aegean and Ionian Seas) ranging from 7.2 to $72.5 \mathrm{~cm}$ in fork length and from 2 to $5400 \mathrm{~g}$ in total weight. The study of the growth bands in spine sections showed that one translucent ring is formed annually during the cold season. The growth parameters estimated $\left(\mathrm{L}_{\infty}=82.99 \mathrm{~cm}, \mathrm{~K}=0.24, \mathrm{t}_{0}=-0.77\right)$ express the growth of the species more realistically than previous studies in the Mediterranean Sea and the Atlantic Ocean.

Keywords: Sarda sarda, age and growth, validation, marginal increment analysis, Mediterranean.

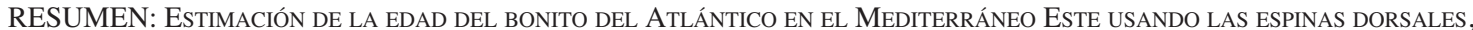
Y VALIDACIÓN DEL MÉTODO. - Se estudiaron los parámetros de crecimiento en 397 especimenes de bonito del Atlántico capturados en el Mediterráneo Este (mares Egeo y Jónico) entre 7.2 y $72.5 \mathrm{~cm}$ de longitud total y de 2 a $5400 \mathrm{~g}$ de peso total. El estudio de las bandas de crecimiento en secciones de espinas mostró que anualmente, durante la estación fría, se forma un anillo translucido. Los parámetros de crecimiento estimados $\left(\mathrm{L}_{\infty}=82.99 \mathrm{~cm}, \mathrm{~K}=0.24, \mathrm{t}_{0}=-0.77\right)$ expresan el crecimiento de la especie de manera más realista que en previos estudios en el Mediterráneo y el Atlántico.
\end{abstract}

Palabras clave: Sarda sarda, edad y crecimiento, validación, análisis de incremento marginal, Mediterráneo.

\section{INTRODUCTION}

The Atlantic bonito, Sarda sarda (Bloch, 1793), is an epipelagic, schooling scombrid found throughout tropical and temperate waters of the Atlantic Ocean, including the Mediterranean and the Black Sea (Collette and Chao, 1975). Despite the fact that the Atlantic bonito is one of the most important commercial species of scombrids exploited in the Mediterranean Sea, relatively little is known about its population biology and stock structure.

Several authors have estimated the age of the Atlantic bonito in different geographical areas using both length frequency analysis and counts of rings in various hard parts. Rodriguez-Roda (1966) estimated the age of the Atlantic bonito on the Atlantic coast of Spain using both length frequency analysis and counts of rings in the vertebrae. Hansen (1989) studied growth in the Atlantic bonito from Argentina using only length frequency analysis. Rey et al. (1986) used vertebrae, spines and scales to estimate age and growth of Atlantic bonito from the western Mediterranean and the Atlantic side of Gibraltar, while Santamaria et al. (1998) used spines and vertebrae in the NW Ionian, in the eastern Mediterranean. In the Black Sea and the Sea of 
Marmara several studies were performed using length frequency analysis (Zusser, 1954; Numann, 1955; Nikolskii, 1957; Tkacheva 1958; Turgan, 1958; Mayorova and Tkacheva, 1959; Demir, 1963) and only Kutaygil (1967) used otoliths. None of these authors has validated the annual formation of translucent zones in the hard parts studied.

The growth rate of fish is an essential component of models used in stock assessment of fish populations and small variations in growth rates can have a significant impact on the outcomes of the population analysis. As Campana (2001) stated, there are many instances in which ageing error has contributed to the serious overexploitation of a population or species (Smith et al., 1995; Chilton and Beamish, 1982; Campana et al., 1990). Many authors suggest the use of validation methods (Chilton and Beamish, 1982; Beamish and McFarlane, 1983; Campana et al., 1990; Smith et al., 1995) such as the determination of the age of first increment formation and the verification of the increment periodicity across the entire range of interest. The main goals of the present study were to estimate age and growth using dorsal fin spines and to validate the use of spines by marginal increment analysis.

\section{MATERIALS AND METHODS}

\section{Sampling scheme}

Atlantic bonito $(n=397)$ of all size categories were obtained from the Greek commercial fishing fleets operating in the east Aegean Sea, west Aegean Sea, Patraikos Gulf and Korinthiakos Gulf (Fig. 1). These specimens were caught using either purse seines with a mesh size in the cod end of $40 \mathrm{~mm}$ (full mesh) targeting small tuna species during the day or purse seines with a mesh size in the cod end of $16 \mathrm{~mm}$ (full mesh) targeting small pelagic species during the night. Few individuals were caught from other artisanal fisheries using long lines and drifting nets. Sampling was carried out during the period 1997-2003, throughout the year.

For each fish, the first spiniform ray of the first dorsal fin was collected, and fork length $\left(\mathrm{L}_{\mathrm{F}}\right)$, total weight $(\mathrm{W})$, sex when possible, as well as date and place of capture were recorded. Sex was determined macroscopically by visual inspection of gonads according to Nikolsky (1963) and Rey et al. (1984).

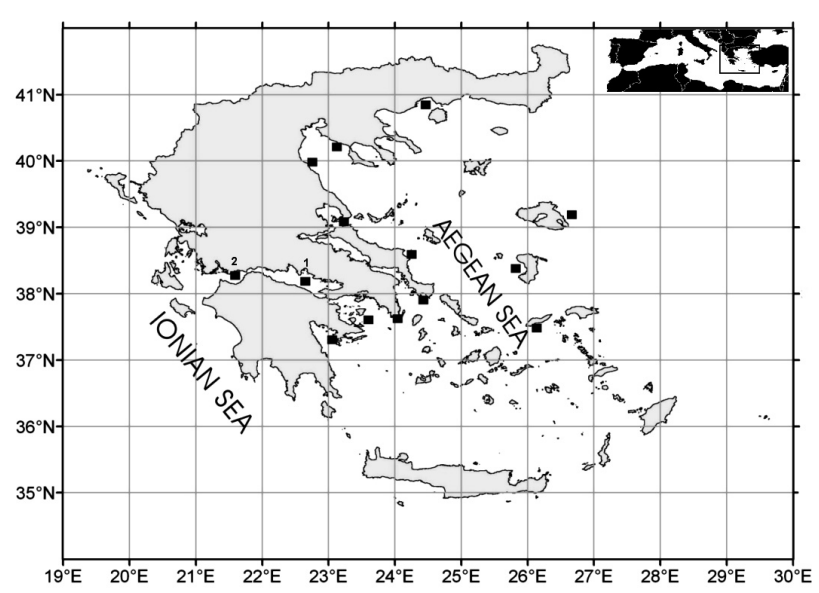

FIG. 1. - Sampling area for the Atlantic bonito, Sarda sarda, in the eastern Mediterranean Sea $(1=$ Korinthiakos Gulf, 2 = Patraikos Gulf).

\section{Age estimation}

The spines were fixed in Epoxini R 800 synthetic resin. Three cross-sections of $c a .0 .7 \mathrm{~mm}$ thick were obtained from each spine at the point near the condyle (González-Garcés and Fariña-Perez, 1983; Megalofonou, 2000) using a low-speed saw and diamond wafering blades. The sections were mounted with a synthetic resin on glass slides and viewed under transmitted light using a Zeiss, Axiolab microscope equipped with an Image Analysis Pro Plus 3.1 image analyser. Growth bands observed under the above optical conditions were distinguished. Translucent zones, which were assumed to be indicative of slow growth, were separated by opaque zones, which were assumed to represent fast growth. Translucent bands were continuous around the perimeter of the spine section (Megalofonou, 2000), but in many specimens were more visible at the rear or at the edge of the section. The total number of translucent bands in spine sections was recorded in order to assign an estimated age to each bonito and build a size-age key. One reader made two readings of each spine independently. When there was disagreement between counts of translucent bands, spines were read for a third time. If agreement could not be reached, those spines were not included in the analysis. The correct identification of the first and second annuli in older fish is the common problem encountered when using spines. In many species the spine nucleus may be reabsorbed and replaced by a hole (vascularisation), which may eliminate the first rings (Casselman, 1983; Kohli, 1989; Mc Farlane and King, 2001). If the first annulus is not identified correctly, fish age 
will be underestimated leading to an overestimation of the growth and natural mortality coefficients with drastic implications in fish stock management (Leaman and Nagtegaal, 1987; Casey and Natanson, 1992). Therefore, we followed the suggestion of Beamish (1981) and Chilton and Beamish (1982) to use the mean diameters of the first and the second annuli in spine sections of young fish to localise their position in older fish. If annuli near the centre of the spine were not visible, due to loss of material by vascularisation, the vascularisation area was measured. Linear regression analysis was performed to obtain the equation between fork length and radius of the first dorsal spine ( $R$ ).

\section{Validation}

The approach to validating the ageing method was based on marginal increment analysis. Observations on the type and frequency of growth zones occurring on the outside margin of each spine per month were made (Cayre and Diouf, 1981; Megalofonou and De Metrio, 2000). Moreover, marginal increment ratio (MIR) analysis was performed to determine the time of band formation using the following equation (Natanson et al., 1995):

$$
\operatorname{MIR}=\left(S D-D_{n}\right) /\left(D_{n}-D_{n-1}\right)
$$

where $\mathrm{SD}$ is the spine diameter, $\mathrm{D}_{\mathrm{n}}$ is the diameter to the last complete band and $\mathrm{D}_{\mathrm{n}-1}$ is the diameter to the penultimate complete band. The mean MIR $( \pm$ S.D.) was plotted monthly in order to locate periodic trends in band formation. An analysis of variance (ANOVA) was used to detect significant differences throughout the course of the year and Tukey tests were performed to demonstrate which months differed from the others. The edge-characterisation analysis was used to determine the period of growth-band formation (Newman and Dunk, 2003). The frequency of translucent zones $(\mathrm{MIR}=0)$ and opaque zones $(\mathrm{MIR}>0.4)$ was plotted monthly. In order to examine the possibility of a link between water temperature and annuli formation we used the data of Vlahakis and Pollatou (1993) from 21 sites in the Aegean and calculated the mean monthly temperature.

\section{Growth}

Student's t test was performed to compare the mean length at age between female and male boni- tos. The VONBER program (Sparre, 1987) was used, allowing parameters to be estimated without transforming the data into linear form. The Von Bertalanffy growth function (VBGF) (von Bertalanffy, 1938) was fitted to data:

$$
\mathrm{L}_{\mathrm{t}}=\mathrm{L}_{\infty}\left(1-\exp \left[-\mathrm{K}\left(\mathrm{t}-\mathrm{t}_{0}\right)\right]\right)
$$

where $\mathrm{L}_{\mathrm{t}}=$ the predicted length at age $\mathrm{t}, \mathrm{L}_{\infty}=$ the mean asymptotic fork length, $\mathrm{K}=$ the growth constant, and $t_{0}=$ the theoretical age at which the fish would have been zero length. The quantity $\Phi=\operatorname{lnk}+$ $2 \operatorname{lnL}_{\infty}$ was computed (Sparre et al., 1989) to compare Atlantic bonito parameters to various studies.

\section{RESULTS}

\section{Age estimation and growth}

Fork length and mass were recorded for 397 bonitos ranging from 7.2 to $72.5 \mathrm{~cm} \mathrm{~L}_{\mathrm{F}}$ and 2 to $5400 \mathrm{~g}$ mass (Fig. 2). Sex was determined in 240 specimens. 157 specimens were immature, 118 males and 122 females. The smallest specimens identified as male and female were $29 \mathrm{~cm}$ in $\mathrm{L}_{\mathrm{F}}$. There was a strong linear correlation between the radius of the first spine of the first dorsal fin and fork length (Fig. 3). Age estimations from spine sections were obtained from a total of 386 bonitos. Only 11 spines that represent $2.85 \%$ of the sample were considered unreadable and rejected from the analysis. Spine sections were eliminated because the bands were too broad and diffuse to determine their number and location accurately. Mean rings diameters are presented in Table 1. In the 92 cases where the diameter of the vascularisation area was higher

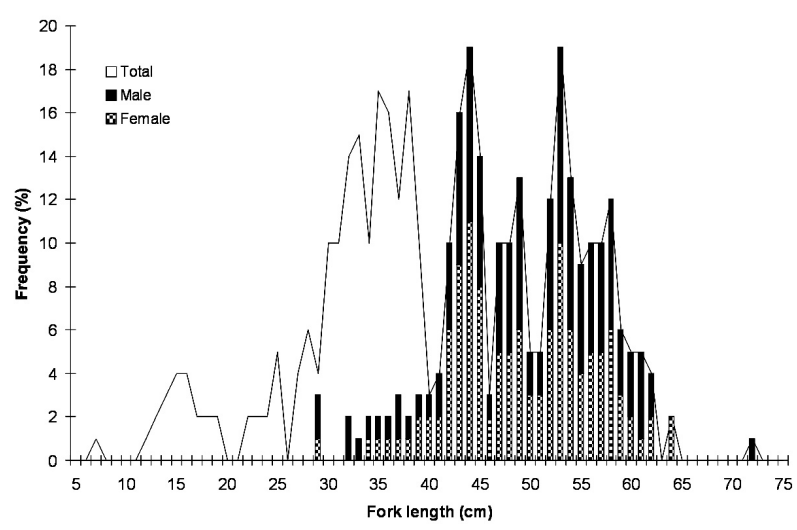

FIG. 2. - Length $\left(\mathrm{L}_{\mathrm{F}}\right)$ frequency distribution of the Atlantic bonito, Sarda sarda, sampled in the eastern Mediterranean Sea. 


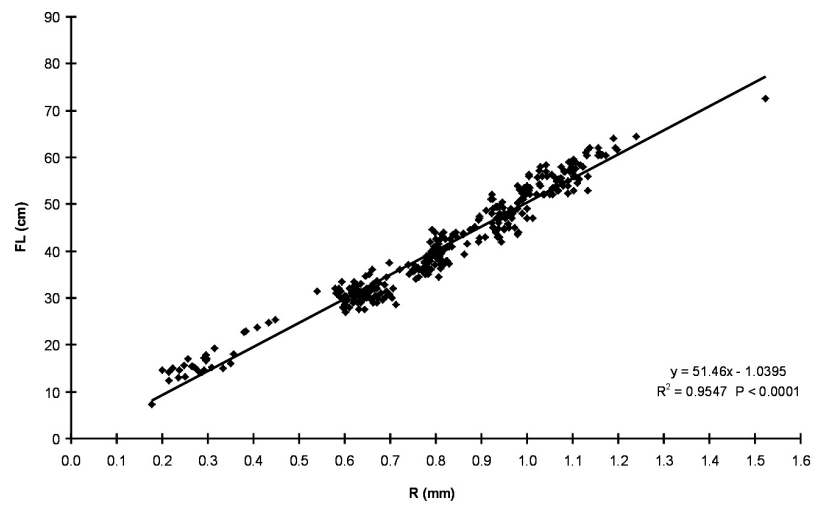

FIG. 3. - Length $\left(\mathrm{L}_{\mathrm{F}}\right)$ regressed on the radius of the first dorsal spine (R) in the Atlantic bonito, Sarda sarda, in the eastern Mediterranean Sea $(\mathrm{N}=397)$.

TABLE 1. - Number of observations (N), mean, standard deviation (s.d.), maximum (max) and minimum (min) diameter of translucent rings on the first spine of the first dorsal fin of the Atlantic bonito, Sarda sarda, from the eastern Mediterranean.

\begin{tabular}{lccccc}
\hline Ring & $\begin{array}{c}\text { mean } \\
(\mathrm{mm})\end{array}$ & $\begin{array}{c}\text { max } \\
(\mathrm{mm})\end{array}$ & $\begin{array}{c}\text { min } \\
(\mathrm{mm})\end{array}$ & $\begin{array}{c}\text { s.d. } \\
(\mathrm{mm})\end{array}$ & $\mathrm{N}$ \\
\hline 1 & 1.2905 & 1.4069 & 1.1131 & 0.0723 & 211 \\
2 & 1.6154 & 1.7350 & 1.5030 & 0.0408 & 214 \\
3 & 1.8567 & 1.7510 & 1.9570 & 0.0367 & 134 \\
4 & 2.0616 & 1.9730 & 2.2130 & 0.0640 & 71 \\
5 & 2.3136 & 2.2420 & 2.3830 & 0.0427 & 10 \\
6 & 2.4406 & 2.4406 & 2.4406 & 0.0000 & 1 \\
7 & 2.8532 & 2.8532 & 2.8532 & 0.0000 & 1 \\
\hline
\end{tabular}

than the mean diameter of the first annulus, an additional annulus was counted. In the 5 cases where the diameter of the vascularisation area was higher than the mean diameter of the second annulus, two additional annuli were counted.

The smallest estimated age was $0+$ and the highest $7+$. Age groups 2 and 3 were the dominant ones in the sample (Table 2). The length-age key of all individuals by age class and length class is presented in Table 2. No significant differences were found in the mean lengths at estimated ages between male and female bonitos (Mann - Whitney, d.f $=239$, $\mathrm{P}>0.05)$. The von Bertalanffy growth model was fitted to mean lengths at estimated ages. The von Bertalanffy equation for the theoretical growth in length for both sexes is presented in Figure 4.

\section{Validation}

MIR was calculated in 307 specimens after exclusion of 90 juveniles that had no translucent zones in their spines sections. MIR was lowest in March and highest in October (Fig. 5). ANOVA detected significant differences during the year
TABLE 2. - Age-length key of 386 Atlantic bonitos, Sarda sarda, from the eastern Mediterranean; $\mathrm{N}$ total number.

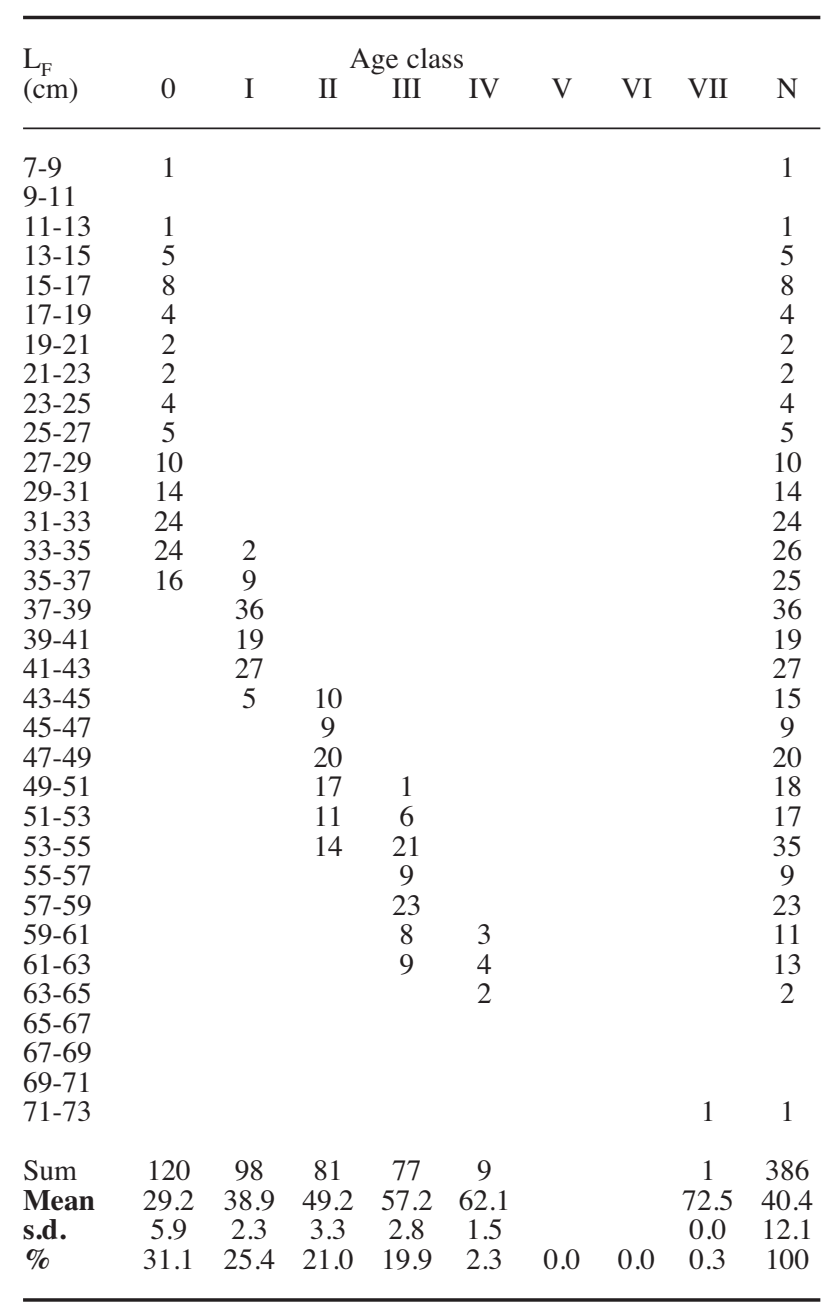

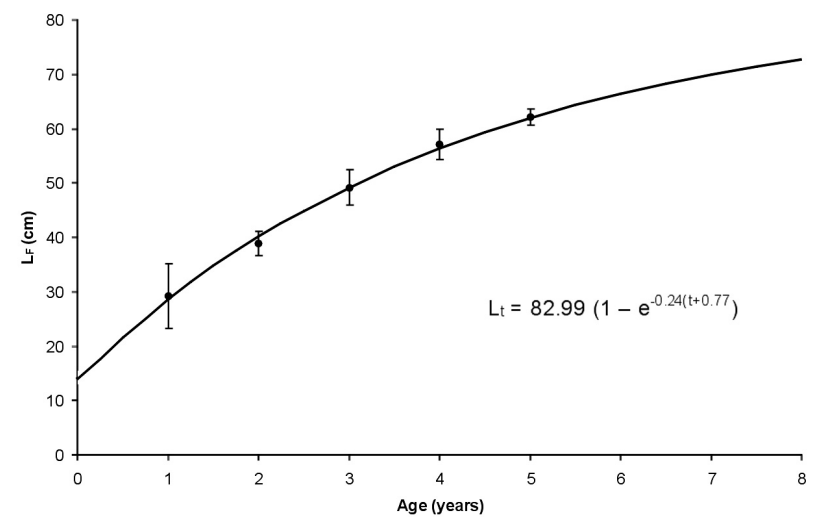

FIG. 4. - Von Bertalanffy growth curve for the Atlantic bonito, Sarda sarda, from the eastern Mediterranean Sea. Black dots indicates mean observed length and bars indicate standard deviation.

(d.f $=306 \mathrm{P}<0.05)$. Tukey's test showed that the MIR in January, February, March, April and May was significantly lower than in July, August, September and October. Furthermore, monthly cate- 

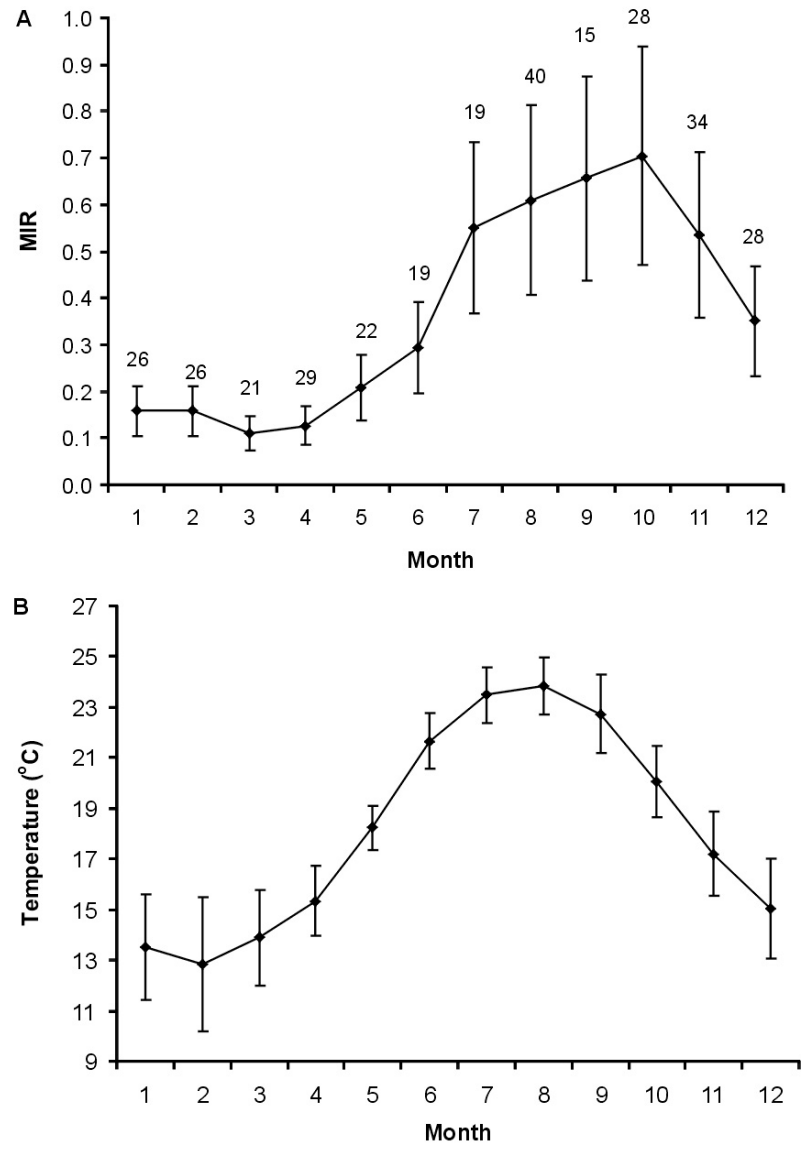

FIG. 5. - A, mean marginal increment ratios (MIR $\pm 95 \% \mathrm{CI})$ by month for the Atlantic bonito, Sarda sarda, from the eastern Mediterranean; B, surface water temperature (Mean $\pm 95 \% \mathrm{CI}$ ) in the Aegean Sea.

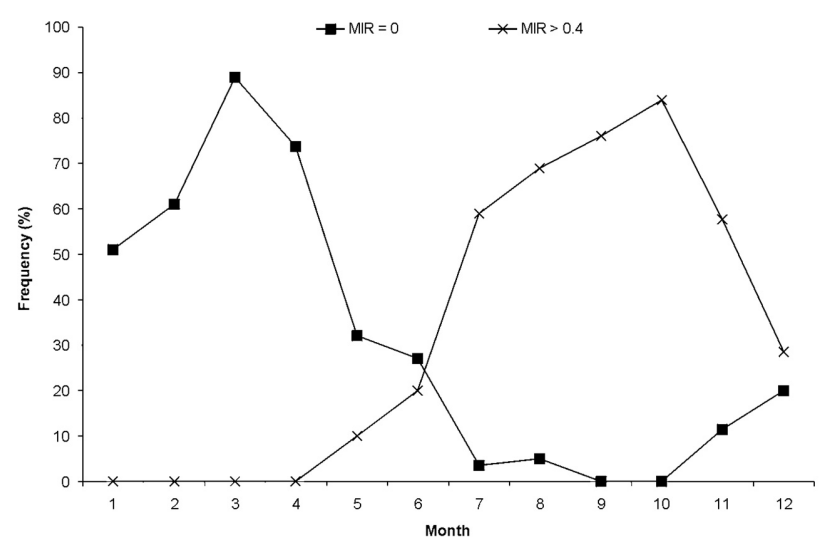

FIG. 6. - Categorization of edges by month for the Atlantic bonito, Sarda sarda, from the eastern Mediterranean. Lines correspond to MIR=0 (translucent zones) and MIR > 4 (opaque zones).

gorisation of spine edge (Fig. 6) indicated that the highest frequency of translucent zones was low between July and October, increased gradually until March and decreased gradually after March. On the other hand, the frequency of opaque zones showed a reverse pattern of fluctuation.

\section{DISCUSSION}

In this study, age and growth of the Atlantic bonito were estimated using spines of the first dorsal fin and, for the first time, the ageing method was validated with marginal increment analysis.

An important assumption in growth studies using various hard parts is that the size of fish and the size of hard parts are closely related throughout the entire life cycle. Many attempts have been made to estimate the age of Atlantic bonito using skeletal hard parts, but without examining this relationship. The strong correlation found in this study between the radius of the first dorsal spine and $\mathrm{L}_{\mathrm{F}}$ indicates that the spine grows proportionally to bonito length and allows for back calculation of $\mathrm{L}_{\mathrm{F}}$ when insufficient length data are available. Many studies on Scombrid species have shown that the relationship between the radius of various hard parts and fish length can be expressed satisfactorily by a straight line (Berkeley and Hood, 1983; Cayré and Diouf, 1983; Compeán-Jimenez and Bard, 1983; GonzálezGarcés and Fariña-Perez, 1983; Megalofonou and de Metrio, 1989), while other studies have shown that there is not always such a correlation (Radtke, 1983; Wilson and Dean, 1983).

The relatively small percentage of spines that were rejected as illegible shows that, if the problem of dissimulation of rings because of vascularisation were solved, the estimation of bonito age with the use of spines could be an effective and relatively practical method in comparison with the use of otoliths and vertebrae that involve damage to the fish. Beamish (1981) compared the spine method with the otolith and scales methods in the Pacific cod, Gadus macrocerphalus Tilesius, and the albacore, Thunnus alalunga (Bonnaterre), and concluded that spine method had an advantage over the two others. Stequert and Conand (2004) noted that the results obtained in the bigeye tuna, Thunnus obesus (Lowe), using spines and otoliths are comparable until the age of 3 years, but spines are not suitable for larger fish. Scales could also be used as a method for age estimation of Atlantic bonito without damaging the fish. This species, however, has scales only in the lateral line and in the corslet. Moreover, Mills and Beamish (1980) and Shirvel (1981) observed that the annual rings are more apparent in spines than in scales, especially in older fish. Megalofonou et al. (2003) found that scales are suitable for the estimation of the albacore's age but there is a probability of underestimation at high ages. 
Determining the time and period of ring formation is one of the most critical steps of ageing fish using hard parts. In the present work, annual deposition of translucent rings was confirmed by marginal increment analysis. The low MIR values from January to April which coincide with the highest frequency of $\mathrm{MIR}=0$ is strong evidence that the Atlantic bonito in the Greek seas forms one translucent zone per year. Ehrhardt et al. (1996) attributed the formation of the translucent areas in rays of fishes to periods of slow growth and the wider dark areas to periods of rapid growth. X-ray analysis has shown that the opaque area in the hard part of fishes is rich in minerals in contrast to the translucent area (Casselman, 1974; 1978) and that the calcium content is reversely correlated with transparency.

The formation of translucent bands has been attributed to various factors that can cause a decreased growth rate in fish, such as reproduction, migration and low temperatures. As reproduction of bonitos takes place from the end of spring to the beginning of summer, the formation of translucent bands cannot be attributed to reproduction. As far as migration is concerned, the data on the bonito are limited. Seasonal migration between the Aegean and the Black Sea has been observed and verified with tagging experiments (Demir, 1963). The migration from the Aegean to the Black Sea begins at the end of April and lasts until the beginning of June, while the opposite migration begins in September and lasts up to the end of November. None of these periods coincides with a translucent ring formation. Moreover, Yoshida (1980) believes that there are schools of bonito that remain in Greek waters all year round. Additionally, in the present study mature bonitos were collected from Greek seas. Hence, migration does not seem to cause the translucent ring formation. The period of translucent ring formation in the bonito coincides with the period of low temperatures in the Aegean. According to Vlahakis and Pollatou (1993), the average temperature of surface waters in the Aegean during the period January-April ranges from 12.8 to $15.3^{\circ} \mathrm{C}$. Temperature considerably influences growth rate in fish. It has been found that the metabolic rate of organisms increases dramatically with the increase in temperature (Hemmingsen, 1960; Kleiber, 1932). We can conclude that the low growth rate during the cold period causes formation of the translucent ring in the spines of the Atlantic bonito.

The value of $L_{\infty}$ that was found in the present study seems to be reliable. It is higher than those of
TABLE 3. - Mean length at age and growth parameters $\left(\mathrm{L}_{\infty}, \mathrm{K}, \mathrm{t}_{0}\right.$ and $\Phi)$ for the Atlantic bonito, Sarda sarda, from the Mediterranean Sea and the Atlantic Ocean.

\begin{tabular}{|c|c|c|c|c|}
\hline \multirow[b]{2}{*}{ Age } & \multicolumn{3}{|c|}{ Mean length $(\mathrm{cm})$} & \multirow[b]{2}{*}{$\begin{array}{l}\text { Present } \\
\text { study }\end{array}$} \\
\hline & $\begin{array}{c}\text { Santmaria et al., } \\
1998\end{array}$ & $\begin{array}{l}\text { Rey et al., } \\
1986\end{array}$ & $\begin{array}{c}\text { Hansen, } \\
1989\end{array}$ & \\
\hline 0 & 34.8 & 37.0 & 42.1 & 28.6 \\
\hline 1 & 50.9 & 51.7 & 49.7 & 40.1 \\
\hline 2 & 57.5 & 57.0 & 54.0 & 49.2 \\
\hline 3 & 64.8 & 63.15 & 57.8 & 56.3 \\
\hline 4 & 70.4 & 71.0 & 61.6 & 62.0 \\
\hline 5 & & & 65.2 & 66.4 \\
\hline \multirow[t]{2}{*}{6} & & & 68.8 & 69.9 \\
\hline & & & 71.7 & 72.7 \\
\hline \multicolumn{5}{|c|}{ Von Bertallanfy parameters } \\
\hline $\mathrm{L}_{\infty}$ & 80.6 & 80.87 & 74.61 & 82.99 \\
\hline $\mathrm{K}^{\infty}$ & 0.36 & 0.35 & 0.22 & 0.24 \\
\hline $\mathrm{t}_{0}$ & -1.37 & -1.70 & -2.74 & -0.77 \\
\hline$\stackrel{0}{\Phi}$ & 3.37 & 3.36 & 3.09 & 3.21 \\
\hline
\end{tabular}

other researchers (Table 3) and closer to the maximum length values recorded. According to the FishBase (Froese and Pauly, 2005), the largest known individual was $91 \mathrm{~cm}$ long and was caught in the western Atlantic. In the Mediterranean the largest known individual was $85 \mathrm{~cm}$ long and was caught in the Black Sea. The slightly lower $\Phi$ quantity (Table 3 ) perhaps reflects the trophic conditions of the Aegean Sea, one of the most oligotrophic regions (Ignatiades, 1998) of the overall oligotrophic Mediterranean (Estrada, 1996). The closer to zero $\mathrm{t}_{0}$ in the present study shows that the growth equation estimated expresses more realistically the growth of the species in comparison with previous studies (Table 3), probably due to the presence of a lot of small individuals in the sample.

In response to a growing demand for tuna, and after the overexploitation of large tuna species, attention has been focused on smaller tuna or tunalike species such as the bonitos (Yoshida, 1980). According to the criterion of Musick et al. (2000), the bonito in the eastern Mediterranean is a species with a medium growth rate and might be vulnerable to intensive exploitation. Thus, the growth parameters presented in this study may prove to be valuable information to be taken into account in future management measures in the area.

\section{ACKNOWLEDGMENTS}

This study was carried out at the Department of Biology of the National and Kapodistrian University 
of Athens, Greece, and was partially funded by the EC (study 96/093) and National Funds (Kapodistria projects). The Propontis Foundation provided financial support to PhD student Nikos Zaboukas. The authors give special thanks to professors Maria Apostolopoulou and Mariana Veini for their helpful suggestions and support. We are grateful to the two anonymous reviewers for their help with the revision of this article.

\section{REFERENCES}

Beamish, R.J. - 1981. Use of fin-ray sections to age walleye pollock, Pacific cod, and albacore, and the importance of this method. Trans. Amer. Fish. Soc., 110: 287-299.

Beamish, R.J. and G.A. McFarlane. - 1983. The forgotten requirements for age validation in fisheries biology. Trans. Amer. Fish. Soc., 112: 735-743.

Berkeley, S.A. and E.D. Houde. - 1983. Age determination of broadbill swordfish, Xiphias gladius, from the Straits of Florida, using anal fin spine sections. NOAA Tech. Rep. NMFS, 8: $137-143$.

Campana, S.E. - 2001. Accuracy, precision and quality control in age determination, including a review of the use and abuse of age validation methods. J. Fish Biol., 59: 197-242.

Campana, S.E., K.C.T Zwanenburg. and J.N. Smith. - 1990 ${ }^{210} \mathrm{~Pb} / 226 \mathrm{Ra}$ determination of longevity in redfish. Can. J. Fish. Aquat. Sci., 47: 163-165.

Casey, J.G. and L.G. Natanson. - 1992. Revised estimates of age and growth of the sandbar shark (Carcharhinus plumbeus). Can. J. Fish. Aquat. Sci., 49: 1474-1477.

Casselman, J.M. - 1974. Analysis of hard tissue of pike Esox lucius L. with special reference to age and growth. In: T.B. Bagena (ed.), The Ageing of Fish, pp. 13-27. Unwin Brothers, Surrey.

Casselman, J.M. - 1978. Calcified tissue and body growth of north ern pike Esox lucius Linnaeus. Ph. D thesis, Univ. Toronto.

Casselman, J.M. - 1983. Age and growth assessment of fish from their calcified structures - techniques and tools. NOAA Tech. Rep. NMFS, 8: 1-17.

Cayré, P.M. and T. Diouf. - 1981. Croissance de la thonine, Euthynnus alletteratus (Rafinesque 1810), établie a partir de coupes transversales du premier rayon de la nageoire dorsal. ICCAT Col. Vol. Sci. Pap., 15: 196-202.

Cayré, P.M. and T. Diouf. - 1983. Estimating age and growth of little tunny, Euthynnus alletteratus, of the coast of Senegal, using dorsal fin spine sections. NOAA Tech. Rep. NMFS, 8: 105-110.

Chilton, D.E. and R.J. Beamish. - 1982. Age determination methods for fishes studied by the Groundfish Program at the Pacific Biological Station. Can. Spec. Publ. Fish. Aquat. Sci., 60: 1-102.

Collette, B.B. and L.N. Chao. - 1975. Systematics and morphology of the bonitos (Sarda) and their relatives (Scombridae, Sardini). Fis.Bull., 73: 516-625.

Compeán-Jimenez, G. and F.X. Bard. - 1983. Growth increments on dorsal spines of eastern Atlantic bluefin tuna, Thunnus thyn$n u s$, and their possible relation to migration patterns. NOAA Tech. Rep. NMFS, 8: 77-86.

Demir, M. - 1963. Synopsis of biological data on bonito Sarda sarda (Bloch) 1793. FAO Fish. Rep., 6: 101-129.

Ehrhard, N.M., R.J Robbins and F. Arocha. - 1996. Age validation and growth of swordfish, Xiphias gladius, in the Northwestern Atlantic. ICCAT Col. Vol. Sci. Pap., 45(2): 358-367.

Estrada, M. - 1996. Primary production in the northwestern Mediterranean. Sci. Mar., 60(2): 55-64.

Froese, R. and D. Pauly. - 2005. FishBase. http://www.fishbase.org. November 2006.

González-Garcés, A. and A.C. Fariña-Perez. - 1983. Determining age of young albacore, Thunnus alalunga, using dorsal spines. NOAA Tech. Rep. NMFS, 8: 117-122.

Hansen, J.E. - 1989. Length growth of the bonito (Pisces,
Scombridae, Sarda sarda). Physis, 47: 13-19.

Hemmingsen, A.M. - 1960. Energy metabolism as related to body size and respiratory surfaces, and its evolution. Rep. Steno Mem. Hosp. Nord. Insulinlab., 9: 1-110.

Ignatiades, L. - 1998. The productive and optical status of the oligotrophic waters of the southern Aegean Sea (Cretan Sea), eastern Mediterranean. J. Plankton Res., 20: 985-995.

Kleiber, M. - 1932 .Body size and metabolism: Hilgardia, 6: 315-353.

Kohli, M.P.S. - 1989. The pectoral spine as an indicator of age in Heteropneustes fossilis (Bloch). J. Fish Biol., 35: 155-156.

Kutaygil, N. - 1967. Preliminary age analysis of Mullus barbatus L. and Merlucius merlucius L. in the Sea of Marmara and some pelagic fish of Turkey. Proc. Tech. Pap. Gen. Fish. Counc. Medit. FAO 8: 361-383.

Leaman, B.M. and D.A. Nagtegaal. - 1987. Age validation and revised natural mortality rate for yellowtail rockfish. Trans. Amer. Fish. Soc, 116: 171-175.

Mayorova, A.A. and K.S. Tracheva. - 1959. Distribution and conditions of reproduction of pelamid (Sarda sarda) in the Black sea according to data for the period 1956-1957. Proc. Tech. Pap. Gen. Fish. Counc. Medit., FAO, 5: 509-514.

McFarlane, G.A. and R. King. - 2001. The validity of the fin-ray method of age determination for lingcod (Ophiodon elongatus). Fish. Bull., 99: 459-464.

Megalofonou, P. and G. de Metrio. - 1989. Stima dell'età e dell'accrescimento del pesce spada (Xiphias gladius L.) del Mar Egeo mediante lo studio dei raggi spiniformi della pinna anale. Nuova Thalassia, 10: 1.

Megalofonou, P. and G. de Metrio. - 2000. Age estimation and annulus-formation in dorsal spines of juvenile bluefin tuna, Shunnus thynnus L., from the aediterranean. J. Mar. Biol. Assoc. UK, 80: 753-754.

Megalofonou, P. 2000. Age and growth of Mediterranean albacore. J. Fish Biol., 57: 700-715.

Megalofonou, P., C. Yannopoulos and J.M. Dean. - 2003. The potential use of scales for estimating age and growth of Mediterranean albacore (Thunnus alalunga). J. Appl. Ichthyol., 19: 189-194.

Mills, K.H. and R.J. Beamish. - 1980. Comparison of fin-ray and scale age determinations for lake whitefish (Coregonus clupeaformis) and their implications for estimates of growth and annual survival. Can. J. Fish. Aquat. Sci., 37: 534-544.

Musick, J.A., M.M. Harbin, S.A. Berkeley, G.H. Burgess, A.M. Eklund, L. Findley, R.G. Gilmore, J.T. Golden, D.S. Ha, G.R. Huntsman, J.C. McGovern, S.J. Parker, S.G. Poss, E. Sala, T.W. Schmidt, G.R. Sedberry, H. Weeks, and S.G. Wright. 2000. Marine, estuarine, and diadromous fish stocks at risk of extinction in North America (exclusive of Pacific salmonids). Fisheries, 25: 6-30.

Natanson, L.J., J.G. Casey and N.E. Kholer. - 1995. Age and growth estimates for the dusky shark Carcharhinus obscurus in the western north Atlantic Ocean. Fish. Bull.993: 116-126.

Newman, S.J. and I.J. Dunk. - 2003. Age validation, growth, mortality, and additional population parameters of the goldband snapper (Pristipomoides multidens) off the Kimberley coast of northwestern Australia. Fish. Bull., 101: 116-128.

Nikolskii, G.W. - 1957. Spezielle Fishchkunde. VEB Deutscher Verlag der Wissenschaften, Berlin.

Nikolsky, G.V. - 1963. The Ecology of Fishes. Academic Press. London.

Numann, W. - 1955. Croissance et migrations des pelamides (Sarda sarda) dans les eaux de la Turqiue. Proc. Tech. Pap. Gen. Fish. Counc. Medit, FAO, 3: 377-379.

Radtke, R.L. - 1983. Otolith formation and increment deposition in laboratory-reared skipjack tuna, Euthynnus pelamis, larvae. NOAA Tech. Rep. NMFS, 8: 99-103.

Rey, J.C., E. Alot and A. Ramos. - 1984. Sinopsis biológica del bonito, Sarda sarda (Bloch), del Mediterráneo y Atlántico Este. ICCAT Col. Vol. Sci. Pap., 20: 469-502.

Rey, J.C., E. Alot and A. Ramos. - 1986. Growth of the Atlantic bonito (Sarda sarda Bloch, 1793) in the Atlantic and Mediterranean area of the Strait of Gibraltar. Inv. Pesq., 50(2): 179-185.

Rodriguez-Roda, J. - 1966. Estudio de la bacoreta, Euthynnus alleteratus (Raf.), bonito, Sarda sarda (Bloch) y melva, Auxis thazard (Lac.), capturados por las almadrabas españolas. Inv. 
Pesq., 30: 247-292.

Santamaria, N., L. Sion, M. Cacucci, and G. De Metrio. - 1998. Età ed accrescimento di Sarda sarda (Bloch, 1973) (Pisces, Scombridae) nello Ionio settentrionale. Biol. Mar. Medit., 5: 721-725

Shirvell, C.S. - 1981. Validity of fin-ray ageing from brown trout. J. Fish Biol., 18: 377-383.

Smith, D.C, G.E. Fenton, S.G. Robertson, and S.A. Short. - 1995. Age determination and growth of orange roughy (Hoplostethus atlanticus): a comparison of annulus counts with radiometric ageing. Can. J. Fish. Aquat. Sci., 52: 391-401.

Sparre, P. - 1987. Computer programs for fish stock assessment. Length-based fish stock assessment (LFSA). FAO Fish. Tech. Pap., 101(2): 1-218.

Sparre, P., E. Ursin and S.C. Venema. - 1989. Introduction to tropical fish stock assessment. Part 1: manual. FAO Fish. Tech. Pap., 306(1): 1-337.

Stequert, B. and F. Conand. - 2004. Age and growth of bigeye tuna (Thunnus obesus) in the Western Indian Ocean. Cybium, 28: $163-170$.

Tkacheva, K.C. - 1958. Conditions of pelamids stocks in the Black sea and fishery prospectives. Rybn. Khoz., 34: 10-13.

Turgan, S. -1958 . The age determination of bonitos and pelamis Balik. Balikcilik, 6(3): 18-20.

Vlahakis, G.N and R.S. Pollatou. - 1993. Temporal Variability and Spatial Distribution of Sea Surface Temperatures in the Aegean Sea. Theor. Appl. Climatol., 47: 15-23.

von Bertalanffy, L. - 1938. A quantitative theory of organic growth (Inquiries on growth laws. II). Hum. Biol., 10(2): 181-213.

Wilson, C.A. and J.M. Dean. - 1983. The potential use of sagittae for estimating age of Atlantic swordfish, Xiphias gladius. NOAA Tech. Rep. NMFS, 8: 151-156.

Yoshida, H.O. - 1980. Synopsis of biological data on bonito of the genus Sarda. FAO Fisheries Synop. 118, NOAA Tech. Rep. NMFS Circ., 432.

Zusser, S.G. - 1954. Biology and fishery for bonito in the Black Sea. Tr. VNIRO, 28: 160-174.

Scient. ed.: B. Morales-Nin.

Rceived February 22, 2007. Accepted July 19, 2007.

Published online October 10, 2007. 